\title{
Chapter 9 \\ What We Have Learned and How We May Proceed
}

\author{
Mark Sanders, Axel Marx and Mikael Stenkula
}

\begin{abstract}
In this chapter, the editors conclude this volume and draw the most important lessons that can be drawn from the FIRES project. The editors highlight theoretical lessons, methodological innovations, and policy implications.
\end{abstract}

Keywords Entrepreneurship $\cdot$ Entrepreneurial society $\cdot$ Institutional reforms

This book marks the conclusion of the project "Financial and Institutional Reforms for the Entrepreneurial Society" (FIRES)—a European Union project launched in 2015 as part of the Horizon 2020 program to restore Europe's ability to innovate, grow, and create jobs over the coming decades. By 2015, the mood in Europe was gloomy. The global financial and ensuing Euro crisis had put severe strains on European solidarity and weakened especially the southern Member States. The ambitious Lisbon Agenda to make Europe the world's most innovative continent by 2010 failed to deliver on its promises. The Brexit vote, the Syrian refugee crisis, the backsliding rule of law and rise of populist movements in several European Member States and now the Corona pandemic have strengthened the need for the European Union to reinvent itself and return Europe on the path to inclusive, sustainable, and innovative growth. We therefore believe that since its start, the FIRES project has only gained in importance and urgency.

In the project, we identified the entrepreneurial society as the way forward. The entrepreneurial society is an open society in which ideas can compete on a level playing field and challenge the status quo. First described by Schumpeter (1911), an entrepreneurial society offers opportunity to all and organizes society to support productive entrepreneurship that will generate innovation, jobs, and growth while

\footnotetext{
M. Sanders $(\varangle)$

Utrecht School of Economics, Utrecht University, Utrecht, The Netherlands e-mail: m.w.j.1.sanders@uu.nl
}

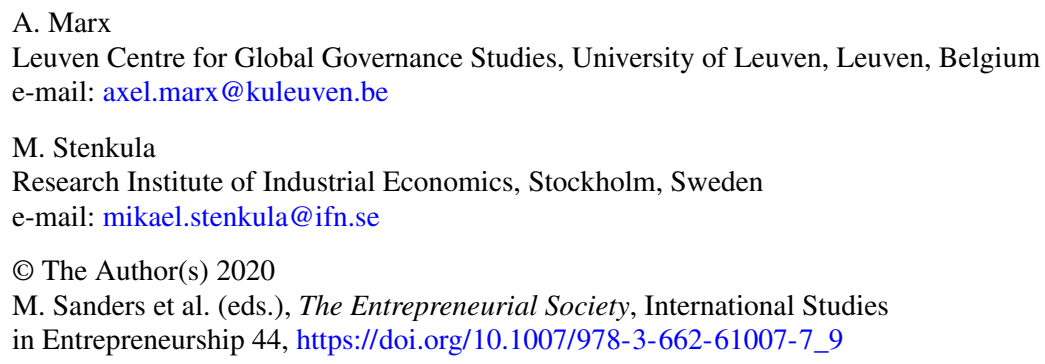


solving the many social and ecological challenges that Europe faces. The European Union (EU) can only (re)assert its place on the global technology frontier by channeling more of its resources and talent to the small scale, innovative, and, therefore, also risky ventures that develop and test solutions for tomorrow, in business and beyond. In an entrepreneurial society, the institutions are such that productive entrepreneurial experimentation is both made possible and encouraged. In our project, we propose seven steps to design, implement, and evaluate reforms that help develop the entrepreneurial society across Europe.

In the companion volume to this book (Elert et al. 2019), our project identified 50 proposals for reform in six key areas of policymaking that would support the mobilization and allocation of human, financial, and knowledge resources for entrepreneurial activity. In this volume we explicitly recognize the diversity of institutional arrangements in the EU as well as the multi-level nature of EU policymaking. An entrepreneurial growth and innovation strategy for the EU cannot be a "one-size-fits-all" basket of proposals.

To identify the appropriate set of interventions in a given context, careful analysis is required. Hence, this volume highlighted the diverse and historically deeply rooted institutional foundations of EU Member States and introduced the tools we developed for analyzing the entrepreneurial ecosystem before turning to reforms. It has also introduced a policy analysis of how and at which levels of governance an effective reform strategy must be formulated in the context of European policymaking. Developing these tools required a broad, multidisciplinary approach. The project, including this book, has included thoughts and ideas of scholars from a range of different fields such as history, economics, geography, management, political science and law.

As the proof of the pudding is in the eating, we then illustrate the practical usefulness of our approach by analyzing Italy, Germany, and the UK in depth and formulate a reform strategy for these countries using our seven-step approach. These three countries were chosen to broadly represent Europe's institutional families. ${ }^{1}$

We draw some important lessons from this exercise. The first is theoretical: building on the work of Schumpeter (1911), Baumol (1990), and Audretsch and Thurik $(2000,2001)$, our project has confirmed that institutions enable or inhibit the allocation of resources to the challengers of the status quo that drive productive entrepreneurial venturing. Therefore, to build an entrepreneurial economy and society, institutional reforms are required. Our application of historical analysis, however, has shown that, due to strong path- and interdependencies, not all institutions are so easily reformed. Echoing the work of Williamson (2000) and new institutional economics, we recognize that some institutions are more deeply embedded than others. Moreover, it is the way institutions actually operate, not how they appear in law or data, that matters. Consequently, it is the functions that institutions perform, rather than the specific shape they take in any given context, that should be the focus of efforts to reform.

\footnotetext{
${ }^{1}$ In the Varieties of Capitalism (VoC) terminology they represent European examples of a mixed (or Mediterranean) market system, a coordinated market and a liberal market, respectively.
} 
To make this more concrete, we can look at the example of universities. Based on cross-sectional and panel data evidence, many have concluded that the presence of a university promotes knowledge-intensive entrepreneurial venturing in its direct surroundings. The university campus serves as a hotbed for entrepreneurship. But university knowledge can spill over to economic activity through productive entrepreneurship in many shapes and forms. The most obvious is perhaps the campus-based university spinoff through a USA-style tech transfer office on a landgrant college that was indeed founded with a mission to disseminate knowledge to business. But that is as much a manifestation of USA history as it is a measure of knowledge spillovers. In a different, say German or Italian context, where universities have traditionally fought to minimize or exclude outside influences (e.g., the Church and the State) in research and curriculum, the same spillover may take the form of educated graduates joining an off-campus research institute and developing new ideas in close collaboration with incumbent firms. Given the deep-rooted institutional context of the German university, perhaps the reform should aim to facilitate the flow of knowledge from universities to firms via the channels that already exist, rather than setting up a tech transfer office and copying the USA Bayh-Dole Act in a context where the institutional framework simply does not support it.

These theoretical lessons have implications for the methods that should be applied in analyzing the need, scope, and opportunities for institutional reform in any specific country, region, or locality. As much as can be learned from comparing uniformly defined indicators and their impacts across regions and countries, doing so implicitly assumes that the same observed variables reflect the same underlying mechanisms across regions with potentially very different institutional contexts. Methodologically, we therefore stress the need to triangulate methods. It is a good start, but not enough to compare regions on a set of well-defined variables to identify their weaknesses, strengths, and bottlenecks. Such analyses need to be complemented with careful historical analysis to understand the specifics of the local, regional, and national institutional contexts as well as survey-based and qualitative information on how local entrepreneurial ecosystems function and how they could be improved.

These methodological innovations also have important policy implications. There are many ways in which an ecosystem can channel resources to (or away from) productive entrepreneurs. And there are many, potentially highly relevant, complementarities among these institutions. Proposing a one-size-fit-all reform strategy to promote the European entrepreneurial society is then beside the point. Bavaria cannot be(come) Silicon Valley or London, nor should it want to. Instead, the focus should be on promoting access to resources for challengers of the status quo in all of these specific institutional contexts.

The lack of a clear and unambiguous policy prescription also implies that policymakers have to make some tough choices, as there are inevitable tensions between the various approaches. First there is the tension between universalist and particularist analysis. The Varieties of Capitalism (VoC) and historical analysis approach in Chaps. 2 and 4 clearly stress that every constellation of institutions is unique, whereas the Regional Entrepreneurship and Development Index (REDI) and Geographic, Macro, and Regional (GMR) modeling approaches of Chap. 3 rely on uniformly 
defined, internationally comparable indicators and estimates of average effects to quantify bottlenecks and predict the impact of alleviating them. On the one hand, particularists will claim that every economy has to be analyzed separately, and no general model can be used to analyze the impact of a specific policy, strategy, or reform. Moreover, one cannot compare economies and extract "best practices" from one country and expect them to work similarly in another country. On the other hand, universalists - including most economists - will claim that the basic mechanisms under study are sufficiently similar across contexts, and the relevant diversity between them can be adequately addressed by including a broad variety of indicators in the overall index, carefully distinguishing between complements and substitutes in the ecosystem and controlling for institutional characteristics.

In this book, we do not want to argue the case one way or the other: We firmly believe that the approaches should complement each other. The entrepreneurial ecosystem approach (Stam 2015; O'Connor et al. 2018) brings the two approaches together and proposes universal theoretical concepts to systematize particularistic empirical data.

A second, perhaps somewhat related tension in our book exists between reforms that are desirable and those that are feasible. Once universalists and particularists have agreed on a set of desirable interventions in a specific context, there is always the reality check of their political and legal feasibility. Policymaking in the EU involves navigating the complex tangle of treaties, legislation, and agencies that have and give mandates and competences. The scope for encompassing reforms is often severely limited by the complexities of policymaking in the EU. Legal competencies are distributed between the EU and its Member States in a set of treaties that, although not set in stone, are politically difficult to change. Moreover, the allocation of these competencies was not arranged with making effective entrepreneurship policy in mind. The appropriate governance level for each of the 50 reform proposals in Elert et al. (2019) was identified and provided in that volume. Chapter 5 in this volume provides an analysis of Europe's current entrepreneurship policies to illustrate the complex interwoven structure of actors and competencies involved. Chapter 5 clearly conveys the message that implementing reforms at the appropriate level may be quite challenging in the existing legal frameworks. We need to be aware of this tension and consequently be modest in our expectations but, despite of this, ambitious in our efforts.

A final, politically highly relevant tension that the work in Chap. 3 and the country studies force us to address, is the one between the inclusion of people and of regions. In line with the aim of the Horizon 2020 program, the EU aims for inclusive and sustainable growth. We understood this to mean, inclusion of citizens. However, the proposals and reform strategies proposed in this volume are likely to benefit already prosperous cities and regions the most. Creating more opportunities for more people implies that people and resources become more footloose and will tend to concentrate in places where they can benefit from economies of agglomeration, knowledge spillovers, and network externalities. Unfortunately, hopeful models predicting an almost automatic trickle-down effect to the backward regions do not find much support in the data. This sits uncomfortably with policymakers that are elected and hope 
to be reelected by a geographically delimited constituency. The flexibility of people and resources throughout the EU is not likely to spread economic activity and prosperity equally across space. In fact, it may drive further divergence between core and peripheral, urban and rural, regions and countries. Chapters 3, 6, 7, and 8 in this volume address this issue. It is important to be aware that, even if all citizens benefit, not all regions in the EU will. In our project, it is the well-being of its people, not the fate of the politicians representing distinct administrative geographical units that is the primary concern in our reform proposals. That said, effective automatic transfer schemes that will help to maintain economic prosperity throughout the EU might be needed to ensure stable support in the long run.

In conclusion, the FIRES project ended formally on May 31, 2018, but the real work has only just begun. Policymakers at all levels in the EU now need to carefully navigate the tensions we discussed above and start experimenting with reforms that channel resources to challengers in their constituencies. More than a call for a set of specific reforms, our project is a call for experimentation. Carefully designed and evidence-based interventions now need to be tested on the ground. We stand ready to support policymakers who are willing to take up our call to action.

\section{References}

Audretsch DB, Thurik AR (2000) Capitalism and democracy in the 21st century: from the managed to the entrepreneurial economy. J Evol Econ 10(1-2):17-34

Audretsch DB, Thurik AR (2001) What's new about the new economy? Sources of growth in the managed and entrepreneurial economies. Ind Corp Change 10(1):267-315

Baumol W (1990) Entrepreneurship: productive, unproductive and destructive. J Polit Econ 98(5):893-921

Elert N, Henrekson M, Sanders M (2019) The entrepreneurial society: a reform strategy for the European Union. Springer, Berlin

O'Connor A, Stam E, Sussan F, Audretsch DB (2018) Entrepreneurial ecosystems. Springer, Berlin Schumpeter J (1911) The theory of economic development. Cambridge University Press, Cambridge, MA

Stam E (2015) Entrepreneurial ecosystems and regional policy: a sympathetic critique. Eur Plan Stud 23(9):1759-1769

Williamson OE (2000) The new institutional economics: taking stock, looking ahead. J Econ Lit 38(3):595-613 
Open Access This chapter is licensed under the terms of the Creative Commons Attribution 4.0 International License (http://creativecommons.org/licenses/by/4.0/), which permits use, sharing, adaptation, distribution and reproduction in any medium or format, as long as you give appropriate credit to the original author(s) and the source, provide a link to the Creative Commons license and indicate if changes were made.

The images or other third party material in this chapter are included in the chapter's Creative Commons license, unless indicated otherwise in a credit line to the material. If material is not included in the chapter's Creative Commons license and your intended use is not permitted by statutory regulation or exceeds the permitted use, you will need to obtain permission directly from the copyright holder.

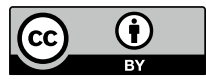

